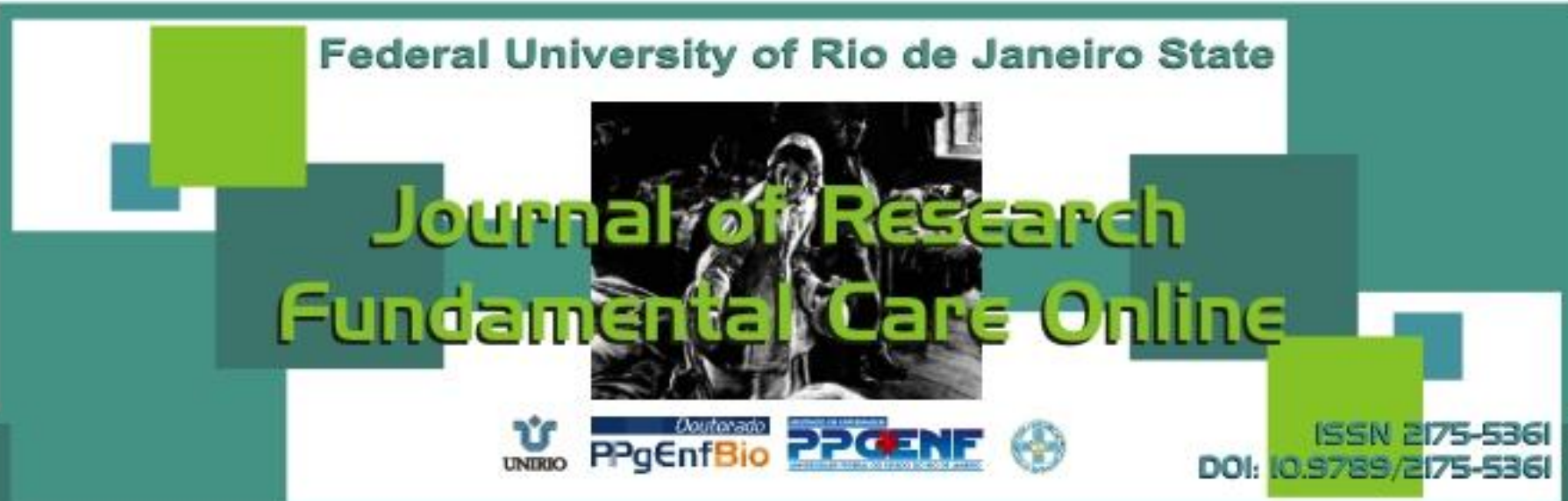

\title{
RESEARCH
}

\section{Children, vulnerability and educative practices}

Criança, vulnerabilidades e práticas educativas

Niños, la vulnerabilidad y prácticas educativas

Emanuelle Marques Souza ${ }^{1}$, Auriane Fátima Macedo ${ }^{2}$, Bruna Campos Costa ${ }^{3}$, Florence Romijn Tocantins ${ }^{4}$, Luiz Henrique Chad Pellon ${ }^{5}$, Almerinda Moreira ${ }^{6}$

$\leftrightarrow$ ABSTRACT

Objective: To describe an educational practice based diagnosis of vulnerabilities, aimed at decision making regarding the health of the individuals involved. Method: The methodological approach involved four distinct steps: negotiation with the practice field, ambiencing, data collection and the development of educational practice. Results: The diagnosis of their vulnerability, concerning, among others, the nutritional deficit, permitted to establish the following nursing action: to dialogue with the children, in order to strengthen the pre-existing knowledge about healthy eating. Conclusion: The achievement of educational practice, related to vulnerability diagnosis and supported by the concept of health promotion, requires an approach that considers objective and subjective aspects of living of the population subject of attention. Descriptors: Child care, Health vulnerability, Health promotion, Nursing.

RESUMO

Objetivo: Descrever uma prática educativa baseada em diagnostico de vulnerabilidades, visando à tomada de decisão quanto à saúde dos sujeitos envolvidos. Método: 0 percurso metodológico envolveu quatro etapas distintas: negociação com o campo de prática, ambientação, coleta de dados e desenvolvimento da prática educativa. Resultados: A partir do diagnóstico de vulnerabilidades, relacionados, entre outros, ao déficit nutricional, foi estabelecida a seguinte ação de enfermagem: dialogar com as crianças, visando fortalecer o conhecimento pré-existente sobre a alimentação saudável. Conclusão: A realização de práticas educativas, a partir do diagnóstico de vulnerabilidade e apoiadas na concepção de promoção da saúde, requer uma abordagem que contemple aspectos objetivos e subjetivos de vida do grupo da população, sujeitos da atenção. Descritores: Cuidado da criança, Vulnerabilidade em saúde, Promoção da saúde, Enfermagem.

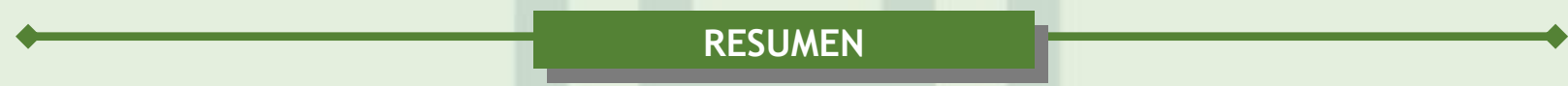

Objetivo: Describir una práctica educativa basada en el diagnóstico de las vulnerabilidades, orientado a la toma de decisiones con respecto a la salud de los individuos involucrados. Método: El enfoque metodológico consistió en cuatro etapas distintas: a negociación con el campo de la práctica agrícola, ambientación, la recolección de datos y el desarrollo de la práctica educativa. Resultados: A partir del diagnóstico de vulnerabilidades, en relación con, entre otros, el déficit nutricional, se estableció la acción de enfermería: diálogo con los niños, con el fin de fortalecer el conocimiento pre-existente sobre la alimentación saludable. Conclusión: La realización de la práctica educativa, desde el diagnóstico de la vulnerabilidad y apoyo de lo concepto de promoción de la salud, requiere un enfoque que tenga en cuenta aspectos objetivos y subjetivos de la vida de la población sujeta de atención. Descriptores: Cuidado del niño, Vulnerabilidad en salud, Promoción de la salud, Enfermería.

${ }^{1}$ Nursing student at the Nursing School Alfredo Pinto-UNIRIO. Scientific initiation scholarship UNIRIO. Member of the Research Laboratory of Nursing History. E-mail: emanuellemarza@hotmail.com. ${ }^{2}$ Nursing student at the Nursing School Alfredo PintoUNIRIO. Monitoring scholar-UNIRIO. E-mail: auri macedo@hotmail.com. ${ }^{3}$ Nursing student at the Nursing School Alfredo PintoUNIRIO. Scientific initiation Scholarship-UNIRIO. Email: brukabruninha@hotmail.com. ${ }^{4} \mathrm{PhD}$ in Nursing, Titular Professor, Department of Public Health Nursing-School of Nursing Alfredo Pinto- Federal University of the State of Rio de Janeiro UNIRIO. E-mail: florence@unirio.br. ${ }^{5}$ Master's Degree in Nursing, Assistant Professor, Department of Public Health NursingSchool of Nursing Alfredo Pinto- Federal University of the State of Rio de Janeiro - UNIRIO. E-mail: Ihpellon@globomail.com. ${ }^{6} \mathrm{PhD}$ in Nursing from the University of São Paulo (2003). Nowadays she is Associate Professor level 4 of UNIRIO, occupying the position of Director of the undergraduate program of the school of Nursing Alfredo Pinto/UNIRIO. Effective member of the Brazilian Association of Nursing-RJ and Director of Social Communication of the Brazilian Academy of the History of Nursing (ABRADHENF). A Founding Member of the Research Laboratory of Nursing History Laphe / SCHOOL of NURSING ALFREDO PINTOUNIRIO. Member of the laboratory for studies in the History of Nursing (LAESHE) of the EERP-USP. E-mail: almerindaprof@yahoo.com.br. 


\section{INTRODUCTION}

his is a descriptive qualitative study on the steps that comprised an educative practice aiming at the promotion of the health of a group of children; age range between 3 and 12 years old who attend a non-governmental organization with social and pedagogical support in the northern zone of Rio de Janeiro.

It was developed by academics of the seventh period of undergraduate program in nursing as an activity of practical teaching curriculum, with theoretical participation and empowerment conception.

The child's ability to compensate for the lack of experience with an excess of receptivity allows them learn in weeks, which for older individuals would take years. ${ }^{1}$ Thus, in order to achieve satisfactory growth and development, the first years of life are the most important in the life of a human being. However, the child is in some way is dependent on the adult human and needs physical stimulation and sensory attributes so that they can achieve a sufficient cognitive growth and the development of their potential to become a more conscientious citizen. ${ }^{2}$

Therefore, educational activities that involve critical pedagogical frameworks, and directed at the construction of healthy life frameworks ${ }^{3}$, become relevant to the issues related to the promotion of child growth and development. At the same time, the practices developed aims to contribute to the construction of knowledge on the possibilities and limitations that these health promotion activities can present for the formation of critical and reflective skills of all involved in the teaching-learning process.

It is worth highlighting that health promotion is intended to strengthen the members of population groups so that as collectivities and individuals, can cope in the most suitable way to determinants and constraints of the health-disease process. Soon, encompasses the perspective of empowerment of communities by targeting their strengthening in decisions relating to their health. ${ }^{4}$

The integral health promotion of the child and the development of actions for the prevention of injuries and assistance are goals that, in addition to the reduction of infant mortality, pointing to the commitment to provide quality of life for those who are in this vital cycle so that they can grow and develop their full potential. ${ }^{2}$

However, this study aims to describe the steps of an educational practice with children based on diagnosis of vulnerabilities, aiming at decision-making regarding the health of the involved subjects. 


\section{METHODOLOGY}

The methodological approach of the study involved four distinct stages, namely: negotiation with the practice field, setting, data collection and development of educational practice.

Two days were selected for negotiation of students with the coordinators from the morning and afternoon shifts, for a preliminary contact in addition to a day for the ambientation. For purposes of this experience report, the ambiance is understood as the insertion in social scenario regarding the scope of health approach, is concerning the general issues and healthcare practices in particular, as part of the community to deal with everything that the environment encompass. ${ }^{5}$

The data collection phase was made by two distinct paths, having as a basis the concept of vulnerability of a group of people understood not only in relation to the alert of social subjects affected, but mainly in that respect. A mobilization of these in the order of "empowerment" and recognition of themselves, as individuals acting on their own health, building for themselves and for the others the notion needs that are the authors and autonomous of their own lives. ${ }^{6}$

Access to objective data - related to living conditions, environment and access to social services and health occurred through electronic search in the Archives of the Data website ${ }^{7}$ on information about the territories and social spaces of life and health of children.

Access to the subjective data, which is the style of life of children, occurred through the development of recreational activities. The ludic activity was prioritized, then, in this educational practice with children because it is a construction site, creation and exploration, by means of which you can remove the production of meanings. The use playful activities in the relationship with children are to develop and give meaning to the context of symbolic interactions of this child. This being so, we ran a ludic activity with the theme on the environment considering it as a space for development of the multiple relationships of the child with the outside where they fall within the meanings attributed to the individual, family and social bodies. ${ }^{8}$

To recognize the individual autonomy limitations of children, which are linked to the family and social relationship areas, we launched the theoretical framework of Wright and Leahey ${ }^{9}$ to formulate an approximate evaluation of their family structures and the influence of this on their cognitive, affective and behavioral education.

Thus, this study was developed supported in foundational perspective that autonomy must be one of the central objectives of health work, both in the conception of attention as well as assistance and healthcare. With this understanding, the interventions in the health and education field should pervade the construction of subjects through technological tools to achieve improvements in their social and reducing vulnerabilities, by strengthening the autonomy and empowerment of their choices. ${ }^{10}$ 
In order to get a diagnosis to trace the vulnerabilities and thus propose actions that are instruments of reflections and interventions, we seek to bridge the information obtained through ludic activity, with data obtained from the collection of information in the official database ${ }^{7}$ and data obtained with the weight and height measurement of the children.

The vulnerability of the members of one population group designates the susceptibility of people from this group to situations, problems and health damage considering the realities of their lives. With this understanding, vulnerability to risk not only precedes but also determines all different risks of becoming infected, get sick and die. ${ }^{11}$ Thus, each child - as an integral part of a group of the population, presents a threshold of vulnerability that, when exceeded, resulting in illness.

Through the articulation and analysis of objective data - environments: social and geographic conditions: social and health and access to services, and subjective data lifestyle focus group - it was possible to diagnose as vulnerabilities of the group in question, related situations: respiratory problems, malnutrition, disorders resulting from trauma, pulmonary tuberculosis and traffic accidents.

We defined, for this moment, and as the focus of our attention as nursing students, an educational practice aimed at stimulating the autonomy of children to confronting vulnerability related to malnutrition. The option for the purpose of this relates directly to the fact that the consequences of poor nutrition for school-age children can lead to speech difficulties, school repetition and change in cognitive function. ${ }^{1}$

In parallel we, as a foundation for educational practice, the proposal to achieve national curriculum guidelines, which are expected to graduate in nursing, while academic and professional profile to present to act with a sense of social responsibility and commitment to building citizenship. ${ }^{12}$

The proposed educational activity was to promote the health of children group, aiming to reduce the vulnerabilities identified that, as stated by Ayres et al. ${ }^{6 .}$ Implies the mobilization of social subjects affected, to stimulate recognition of themselves as people who have the potential to act on their own health, building for themselves and for others the notion of need that are autonomous and authors of their own life.

Understanding health as an essential factor for social and human development, we used for the development of educational activities, the pedagogical framework of Paul Freire. ${ }^{13 .}$ This outlook allowed the subsidizing of the construction of a dialogic educational practice, capable of providing an intervention in the world of the subject of attention, to broaden the focus of the educator to capacity for reinvention of the human being in the learning in the autonomy call. Thus, grounded in the perspective of building a dialogic educational practice, it is understood that teaching is not to transfer knowledge because the verb teach brings in its essence the production and construction of knowledge is achieved through the creation of opportunities that allow the educator discuss knowledge and include them in the teaching-learning process. 


\section{RESULTS AND DISCUSSION}

The characteristics of the data set - related to the social environment and geographic conditions, social and health and access to services, in addition to the life-style of the identified group pointed out. Even though $59 \%$ of children interviewed had habits of the regular consumption of carbohydrates in the form of breads and pastas and the same percentage is in the range of normality in relation to Body Mass Index ${ }^{14}$; only $6 \%$ reported doing regular intake of fruit in at least one of their daily meals.

From the diagnosis of vulnerability related, among others, the nutritional deficit was established the following action of nursing: talk with children, aiming to strengthen and enlarge the pre-existing knowledge on healthy nutrition. The central focus was to work around useful information, emphasizing the importance of the active participation of children in the teaching-learning process, by means of educational practice entitled "DISCOVERING ABOUT FRUIT AND HEALTH".

This teaching method was the tasting and palpation fruit, where the children were blindfolded, and they had to discover which fruit it was through touch and taste. Questions were also asked on their degree of knowledge about the fruit and its relationship to health.

The foods prioritized to focus on educational practice were seasonal fruit, due to their high nutritional value, low cost, availability, and can be eaten fresh without undergoing manipulation, which, in the case of children, it is commonly done by others. Despite the accessibility, the purchase and ingestion of such foods are often being neglected in consequence of a massive onslaught of vehicles of information for the consumption of foods rich in saturated fats, carbohydrates and sugars, with strong appeal to fast food. ${ }^{15 .}$

The following fruits were used: banana, orange, apple, watermelon, guava, melon, lemon, mango and peach. Some fruits such as melon and peach were used in the activity regardless of their high price, which allowed us to induce children, reflect on its consumption, considering the economic aspects and individual decision that determines it. During the activity was explained about the advantages and curiosities of fruit, illustrated with figures and pictures for that were complemented the existing information on the benefits accruing from the intake of fruit.

We note that, although children reporting the scarce supply both at home and at daycare, they recognized all the fruits, even those of higher cost through its aroma, texture and flavor. Moreover, they demonstrated pleasure when savoring the fruit, which was supported by the perception of the students due to the insistent requests of the children to repeat the same food intake. It was then possible to detect that the low consumption is due to the low supply and not the negative individual or group because of preference for foods or not satisfied with the taste. 


\section{CONCLUSION}

From the perspective of developing an educational practice focused on health promotion, based on diagnosis of the vulnerability of a group of children, we face while nursing students, with the need to systematize an activity that includes the steps of data collection, planning, implementation and evaluation. Thus, this process helped us in understanding that the educative practices should take into account a previous study of social needs and health which would suggest both for the content to be addressed, as to the methods and techniques to be prioritized in the teaching-learning process.

It was possible to identify that the achievement of educational practices, from the vulnerability diagnosis is supported in the conception of health promotion. This requires an approach, which includes both objective and subjective aspects of the study population group's life without losing sight of the principle of integrality of care and assistance, provided for both the principles of the Health System, as the qualification guidelines for academic and professional nurses.

\section{Acknowledgments}

We emphasize the relevance of the receptivity of the coordinators Ana Maria Sontes and Maria Helena Ferreira of the institution where the activities were developed, because without them and their support and availability such a project would have not materialized. We also acknowledge the Undergraduate nursing students Vanessa Escoffeir Rodrigues da Silva and Renata Carlos Pinto who contributed significantly to the diagnosis of the vulnerability of the group of children and the development of the educational activities.

\section{REFERENCES}

1. Buss PM (coord e editor) Carvalho Al, Silva, DS, Navarro Stotz E, Uribe Rivera FJ, Ferreira JR et al. Promoção da saúde e a saúde pública: contribuição para o debate entre as escolas de saúde pública da América Latina. Rio de Janeiro: Escola Nacional de Saúde Pública, Fundação Oswaldo Cruz; jul 1998.

2. Organização Pan-Americana da Saúde. Manual para vigilância do desenvolvimento infantil no contexto da AIDPI. Washington, D.C.: OPAS, 2005. Disponível em: http://www.bvsde.paho.org/bvsacd/cd61/vigilancia.pdf ; acesso em 04 Ago. 2012.

3. Lopes R, Tocantins FR. Promoção da saúde e a educação crítica. Rev. Interface. Botucatu. 2012; 16(40). Disponível em: http://dx.doi.org/10.1590/S1414-32832012005000009 . Acesso em 04 ago 2012. 
4. Lefevre F, Lefevre AMC. Promoção de Saúde. A negação da negação. Rio de Janeiro. Ed. Vieira e Lent. 2004.

5. Turato ER. Tratado da metodologia da pesquisa clinico-qualitativa: construção teóricoepistemológica, discussão comparada e aplicação nas áreas da saúde e humanas. Petrópolis (RJ): Vozes, 2003.

6. Ayres JRCM, Calazans GJ, Saletti Filho HC, França-Júnior I. Risco, Vulnerabilidade e Práticas de prevenção e promoção de saúde. In: Campos GWS, Minayo MCS, Akerman M, Drumond Júnior M, Carvalho YM (orgs.). Tratado de Saúde coletiva. Rio de Janeiro Hucitec/ Fiocruz. 2006. p.375-417.

7. Prefeitura da Cidade do Rio de Janeiro. Armazém dos dados. Rio de Janeiro. Atualizada em 10 de nov de 2011. Disponível em: http://www.armazemdedados.rio.rj.gov.br/. Acesso em 10 de nov de 2011.

8. Brougere G. A criança e a cultura lúdica. Rev. Fac. Educ. São Paulo, 1998 [acesso em 26 fev 2012]; 24(2). Disponível em: http: //www.scielo.br/scielo.php?script=sci_arttext\&pid=S0102-25551998000200007 . Acesso em 04 ago 2012.

9. Wright LM, Leahey M. Enfermeiras e famílias: um guia para avaliação e intervenção na família. $3^{\text {a }}$ ed. São Paulo: Editora Roca; 2002.

10. Campos RTO, Campos GWS. Co-construção de autonomia: o sujeito em questão. In: Campos GWS, Minayo MCS, Akerman M, Drumond Júnior M, Carvalho YM (orgs.). Tratado de Saúde Coletiva. Rio de Janeiro Ed. Hucitec: Fiocruz; 2006 p.669-688.

11. Nichiata LYI, Bertolozzi MR, Takahashi RF, Fracolli LA. A utilização do conceito "vulnerabilidade" pela Enfermagem. Rev. Latino-am Enfermagem. 2008 [acesso em 04 ago 2012]; 16(5): 923-8. Disponível em: http://www.scielo.br/pdf/rlae/v16n5/pt_20.pdf . Acesso em 04 ago 2012.

12. Ministério da Educação (Brasil). Conselho Nacional de Educação. Resolução CNE/CES Nº 3, de 7 de novembro de 2001. Institui Diretrizes Curriculares Nacionais do Curso de Graduação em Enfermagem; 2001. Disponível em: http://portal.mec.gov.br/cne/arquivos/pdf/CES03.pdf; Acesso em 4 de ago de 2012

13. Freire P. Pedagogia da autonomia. Saberes necessários a prática educativa. $9^{a}$. ed. São Paulo. Paz na Terra; 1996.

14. Ministério da Saúde (Brasil). Vigilância alimentar e nutricional - SISVAN: orientações básicas para a coleta, processamento, análise de dados e informações em serviços de saúde. Brasília: Ministério da Saúde; $2004 . \quad$ Disponível em: http://bvsms.saude.gov.br/bvs/publicacoes/orientacoes_basicas_sisvan.pdf; Acesso em 4 de ago de 2012

15. Koutsantonis MP. Comunicação e consumo de cultura fast food: Uma experiência Giraffas na praça de alimentação. São Paulo. Dissertação [Mestrado em Comunicação e Práticas de Consumo] - Escola Superior de Propaganda e Marketing; 2008. Disponível em: http://www.espm.br/ConhecaAESPM/Mestrado/Documents/Marina\%20P\%20Koutsantonis.pdf; Acesso em 4 de agosto de 2012.

Received on: 04/12/2012

Required for review: 29/05/2013

Approved on: 07/08/2013

Published on: 01/01/2014
Contact of the corresponding author: Almerinda Moreira

EEAP / UNIRIO - Escola de Enfermagem Alfredo Pinto Rua Dr. Xavier Sigaud, 290 - Urca - Rio de Janeiro - RJ - 22.290-180 Email: almerindaprof@yahoo.com.br 